\title{
Characterization of Resistance to the Cereal Cyst Nematode in the Soft White Winter Wheat 'Madsen'
}

Longfei Wu, The National Key Facility for Crop Gene Resources and Genetic Improvement (NFCRI), Institute of Crop Science, Chinese Academy of Agricultural Sciences, Beijing 100081; and Department of Agricultural, Food and Nutritional Science, University of Alberta, Edmonton, Alberta T6G 2P5, Canada; Lei Cui, NFCRI, Institute of Crop Science, Chinese Academy of Agricultural Sciences, Beijing; Institute of Crop Science, Shanxi Academy of Agricultural Sciences, Taiyuan 030031, China; Honglian Li, College of Plant Protection, Henan Agricultural University, Zhengzhou 450002, China; Lei Sun, NFCRI, Institute of Crop Sciences, Chinese Academy of Agricultural Sciences, Beijing; Xiu Gao and Dan Qiu, College of Life Science and Technology, Hebei Normal University of Science and Technology, Qinhuangdao 066004, China; and NFCRI, Institute of Crop Science, Chinese Academy of Agricultural Sciences, Beijing; Yanling Sun and Xiaoming Wang, NFCRI, Institute of Crop Science, Chinese Academy of Agricultural Sciences, Beijing; T. D. Murray, Department of Plant Pathology, Washington State University, Pullman 99164-6430; and Hongjie Li, NFCRI, Institute of Crop Science, Chinese Academy of Agricultural Sciences, Beijing

\begin{abstract}
Wu, L., Cui, L., Li, H. L., Sun, L., Gao, X., Qiu, D., Sun, Y. L., Wang, X. M., Murray, T. D., and Li, H. J. 2016. Characterization of resistance to the cereal cyst nematode in the soft white winter wheat 'Madsen'. Plant Dis. 100:679-685.

The cereal cyst nematode $(\mathrm{CCN})$ has a significant negative impact on production of wheat in China. The presence of pathotypes of both Heterodera avenae and $H$. filipjevi makes it necessary to identify genetic resources with a wide spectrum of resistance. Results of this study confirmed that the soft white winter wheat 'Madsen' was resistant to many different populations of both $H$. filipjevi and H. avenae in both naturally infested fields and artificial inoculation tests in China. Fewer juvenile nematodes penetrated roots of Madsen than susceptible 'Wenmai 19' in the early stages of the interaction between the nematodes and plant. Testing wheat cultivars in the pedigree of

Madsen demonstrated that the $\mathrm{CCN}$ resistance of Madsen was inherited from 'VPM1' via the line 'VPM1/Moisson 951'. Presence of a 2NS chromosome segment from Aegilops ventricosa was detected in Madsen using a VrgalD-specific marker. However, it appears that gene $P m 4 b$ for resistance to powdery mildew (caused by Blumeria graminis f. sp. tritici) was not transferred from VPM1 into Madsen because these cultivars had different reaction patterns against $20 \mathrm{~B}$. graminis f. sp. tritici isolates from China. Madsen serves as an effective source of host resistance from damage caused by $\mathrm{CCN}$.
\end{abstract}

The cereal cyst nematode (CCN; Heterodera spp.) is of global importance as a pathogen of wheat (Triticum aestivum L.) (Smiley and Nicol 2009). This soilborne nematode invades wheat roots, resulting in bushy and knotted root systems. Usually, it is difficult to distinguish $\mathrm{CCN}$ infestation from other soilborne pathogens or abiotic stresses due to their similar aboveground symptoms, including reduced plant height, fewer tillers, premature spike senescence, and poor grain filling. In China, the economic importance of $\mathrm{CCN}$ in wheat production was only recently recognized, despite being detected in wheat fields in central China as early as 1987. In addition to wind and floods, equipment that is used routinely in crop management and harvest may carry $\mathrm{CCN}$-infested soil from one place to another, which facilitates its long-distance spread. CCN has been detected in 16 provinces in China, which accounts for nearly all of the major winter and spring wheat-producing areas in the country (Peng et al. 2009). The damage caused by $\mathrm{CCN}$ in wheat production has been attributed to the lack of resistance in most cultivars or other effective $\mathrm{CCN}$ management practices. Host resistance to $\mathrm{CCN}$ is the preferred management tool because other practices, such as crop rotation, summer fallow, and soil treatment with chemicals, are not effective or are too costly.

Corresponding authors: H. Li; E-mail: lihongjie@caas.cn; and

T. D. Murray; E-mail: tim.murray@wsu.edu

L. Wu and L. Ciu contributed equally to this study.

Accepted for publication 11 September 2015.

http://dx.doi.org/10.1094/PDIS-06-15-0714-RE

(C) 2016 The American Phytopathological Society
In China, most CCN damage on wheat is caused by Heterodera avenae Wollenweber. H. filipjevi (Madzhidov) Stelter has been detected sporadically in Henan, Qinhai, and Ningxia Provinces (Li et al. 2010; Peng et al. 2010) and its importance has been recognized in many wheat-growing regions of the world, including certain areas of Europe, the Middle East, and Asia (Abidou et al. 2005; Elekçioğlu et al. 2009; Holgado et al. 2004). H. filipjevi was recently detected in the Pacific Northwest (PNW) region of the United States (Smiley and Yan 2015).

Genetic resistance to $\mathrm{CCN}$ has been rarely reported in common wheat, except for a few cultivars such as 'AUS 10894' and 'Loros', both of which carry $\mathrm{Crel}$ on chromosome 2BL (Slootmaker et al. 1974), and 'Festiguay', which carries Cre8 on chromosome 6BL (Williams et al. 2003). Several wheat relatives are sources of CCN resistance, including Aegilops ventricosa Tausch. (Delibes et al. 1993; Jahier et al. 1996; Ogbonnaya et al. 2001), A. tauschii Coss. (Eastwood et al. 1994), A. triuncialis L. (Romero et al. 1998), rye (Scale cereale L.) (Taylor et al. 1998), A. variabilis Eig. (Paull et al. 1998), T. durum Desf. (Gao et al. 2012), Thinopyrum intermedium (Host) Barkworth D. R. Dewey, and T. ponticum (Podp.) Barkworth and D. R. Dewey (Li et al. 2012). Although several genes for resistance to $\mathrm{CCN}$ have been documented, they are not universally effective against all pathotypes of the nematode. For example, genes Cre 1, Cre 2, Cre 3, Cre7, and Cre 8 are ineffective against the Hfc-1 pathotype of $H$. filipjevi from Xuchang, Henan Province, China but CreR from rye appeared to be effective (Yuan et al. 2011). Imren et al. (2013) and Smiley et al. (2013) reported that some CCN resistance genes were not effective against $H$. filipjevi populations from Turkey or $H$. avenae populations from the PNW.

The development of CCN-resistant wheat cultivars in China has not been widely successful due to the limited number of effective resistance genes. The presence of both $H$. avenae and $H$. filipjevi 
further complicates efforts to improve resistance to $\mathrm{CCN}$. Identification of sources of $\mathrm{CCN}$ resistance is a priority for wheat breeding programs. In a recent study, 'Madsen' winter wheat, originally released in the PNW (Allan et al. 1989), was identified as highly resistant to H. filipjevi ( $\mathrm{Li}$ et al. 2012). However, whether Madsen is resistant against $H$. avenae that is indigenous to China is not known, because this nematode species is more prevalent than $H$. filipjevi. The origin of resistance to $\mathrm{CCN}$ in Madsen remains to be determined. Madsen has wheat line 'VPM1' in its pedigree (Allan et al. 1989), and cultivars derived from VPM1 have variable levels of resistance to different pathotypes of $H$. avenae (Jahier et al. 2001; Ogbonnaya et al. 2001). Gene Cre5 in VPM1, which originated from A. ventricosa and confers resistance to $H$. avenae (Jahier et al. 2001), was transferred from chromosome $2 \mathrm{NS}$ of $A$. ventricosa onto chromosome 2AS of wheat. VPM1 also carries $P m 4 b$, which was derived from Triticum persicum Vav. ex Zhuk., and confers resistance to powdery mildew caused by Blumeria graminis f. sp. tritici (DC.) Speer (Bariana and McIntosh 1994). Madsen was reported to be moderately resistant to powdery mildew (Allan et al. 1989) but whether $P m 4 b$ is present in Madsen is not known.

The primary goal of this study was to determine the effectiveness of resistance from Madsen against different populations of $H$. avenae and $H$. filipjevi in China. The second objective was to determine the possible origin of $\mathrm{CCN}$ resistance by testing the reactions of the wheat lines that were included in the pedigree of Madsen. The third objective was to examine the reactions to powdery mildew of Madsen.

\section{Materials and Methods}

Plant materials. Soft white winter wheat Madsen (plant introduction [PI] 511673) was developed from the cross VPM1/Moisson 951/2/2*Hill 81 (Allan et al. 1989). Wheat line VPM1 (PI 519303) was derived from a complex cross $A$. ventricosa/T. persicum Zhuk.//3*Marne. Wheat lines VPM1/'Moisson 951' and 'Hill 81' (CItr 17954), which were used to develop Madsen, were included as controls in this study. A. ventricosa line 10, which was used to develop VPM1, was included as a control in the molecular analysis. 'Taikong 6' wheat, developed from a space shuttle treatment of 'Yumai 49', and 'Wenmai 19', developed from the cross 'Lankao 4'/'Wen 2504', were used as moderately resistant and susceptible controls, respectively, in the CCN tests. Zhongzuo 9504 was used as susceptible control in the powdery mildew assesment.
Field assessment of reactions to CCN. In the 2011-12 and 2012-13 cropping seasons, field experiments were carried out to assess reactions of the wheat entries to $H$. filipjevi and $H$. avenae in wheat fields naturally infested with $\mathrm{CCN}$ at Banpopu Village, Xuchang $\left(34.04^{\circ} \mathrm{N}, 113.74^{\circ} \mathrm{E}\right)$ and Qiushe Village, Xingyang $\left(34.74^{\circ} \mathrm{N}, 113.41^{\circ} \mathrm{E}\right)$, Henan Province. The pathotypes of $H$. filipjevi and $H$. avenae in these wheat fields previously were determined to be Hfc- 1 and Ha43, respectively (Fu et al. 2011; Li et al. 2010). Entries were arranged in a randomized complete block design with three replicates. Each plot consisted of three rows, each $2 \mathrm{~m}$ long, with a row spacing of $28 \mathrm{~cm}$. Seed were sown in mid-October each year. During mid-May at the late grain-filling stage (Zadoks growth stage 77; Zadoks et al. 1974), white females on the roots of 10 plants within each plot were visually counted and then averaged to represent the number of white females per plant for that entry and separated into the following categories: resistant $(<5$ white females/plant), moderately resistant (5 to 10 white females/plant), moderately susceptible (11 to 14 white females/plant), susceptible (15 to 25 white females/plant), and highly susceptible (>25 white females/plant) (Nicol et al. 2009).
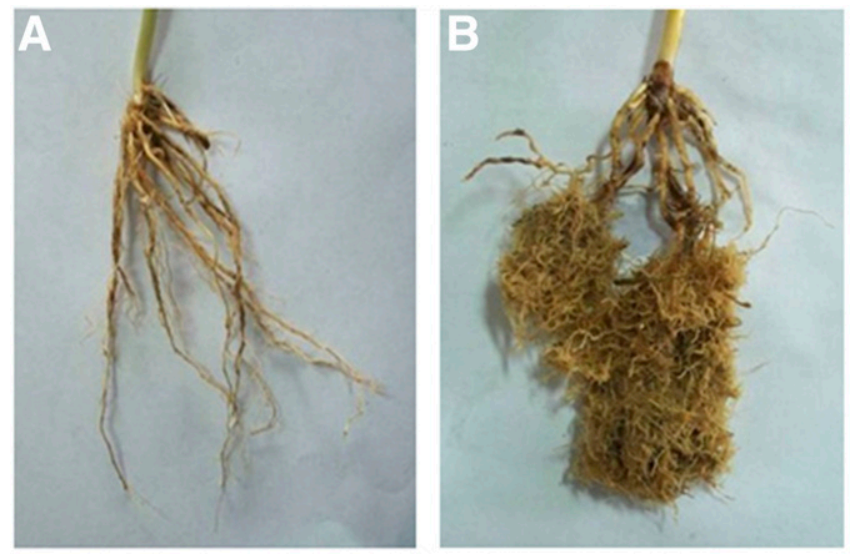

Fig. 1. Roots of field-grown A, Madsen and B, Wenmai 19 at grain filling stage infested by Heterodera filipjevi in Xuchang, Henan Province. Madsen developed normal roots without obvious symptoms, whereas Wenmai 19 developed numerous root nodes and bushy roots as a result of infestation by $H$. filipjevi.

Table 1. Number of white female nematodes on roots and phenotypes of Madsen, VPM1, Taikong 6, and Wenmai 19 inoculated with different populations of Heterodera filipjevi and H. avenae in the greenhouse $\mathrm{y}^{\mathrm{y}}$

\begin{tabular}{|c|c|c|c|c|c|c|c|c|}
\hline \multirow[b]{2}{*}{ Population $^{\mathrm{z}}$} & \multicolumn{2}{|c|}{ Madsen } & \multicolumn{2}{|c|}{ VPM1 } & \multicolumn{2}{|c|}{ Taikong 6} & \multicolumn{2}{|c|}{ Wenmai 19} \\
\hline & Females & PT & Females & PT & Females & PT & Females & PT \\
\hline \multicolumn{9}{|l|}{ H. filipjevi } \\
\hline \multicolumn{9}{|l|}{ Henan } \\
\hline Xuchang & 0 & $\mathrm{R}$ & $0.3 \pm 0.8$ & $\mathrm{R}$ & $4.6 \pm 1.2$ & $\mathrm{R}$ & $21.0 \pm 5.6$ & $\mathrm{~S}$ \\
\hline Linying & 0 & $\mathrm{R}$ & 0 & $\mathrm{R}$ & $22.6 \pm 3.2$ & $S$ & $52.3 \pm 6.5$ & HS \\
\hline Huaiyang & 0 & $\mathrm{R}$ & $\ldots$ & $\ldots$ & $35.5 \pm 7.2$ & HS & $57.2 \pm 15.3$ & HS \\
\hline Luolong & $2.2 \pm 1.2$ & $\mathrm{R}$ & $1.8 \pm 3.9$ & $\mathrm{R}$ & $96.4 \pm 18.7$ & HS & $119.3 \pm 21.6$ & HS \\
\hline Boai & $11.0 \pm 4.3$ & MS & $\ldots$ & $\ldots$ & $40.5 \pm 7.0$ & HS & $44.5 \pm 24.6$ & HS \\
\hline \multicolumn{9}{|l|}{ H. avenae } \\
\hline \multicolumn{9}{|l|}{ Henan } \\
\hline Yanjin & $3.4 \pm 2.7$ & $\mathrm{R}$ & $3.6 \pm 1.7$ & $\mathrm{R}$ & $14.7 \pm 2.4$ & MS & $39.0 \pm 11.6$ & HS \\
\hline Xingyang & $7.7 \pm 5.8$ & MR & $5.8 \pm 6.3$ & MR & $6.3 \pm 4.6$ & MR & $35.8 \pm 4.0$ & HS \\
\hline Shangqiu & $11.7 \pm 11.1$ & MS & $13.6 \pm 6.8$ & MS & $26.7 \pm 5.5$ & HS & $90.1 \pm 16.2$ & HS \\
\hline Qixian & $0.9 \pm 1.3$ & $\mathrm{R}$ & $\ldots$ & $\ldots$ & $14.3 \pm 1.8$ & MS & $29.0 \pm 11.2$ & HS \\
\hline Qingfeng & $1.3 \pm 0.9$ & $\mathrm{R}$ & $\ldots$ & $\ldots$ & $27.6 \pm 6.2$ & HS & $88.3 \pm 10.4$ & HS \\
\hline \multicolumn{9}{|l|}{ Shandong } \\
\hline Heze & $4.0 \pm 1.9$ & $\mathrm{R}$ & $4.0 \pm 2.3$ & $\mathrm{R}$ & $49.3 \pm 9.0$ & HS & $105.4 \pm 20.7$ & HS \\
\hline \multicolumn{9}{|l|}{ Anhui } \\
\hline Yingshang & $1.6 \pm 1.5$ & $\mathrm{R}$ & $3.1 \pm 2.2$ & $\mathrm{R}$ & $14.2 \pm 1.9$ & S & $53.8 \pm 19.9$ & HS \\
\hline
\end{tabular}

${ }^{y}$ Females $=$ number of white females per plant. Figures represent the mean of 20 replicates $(10$ plants by two experiments $) \pm$ standard error. PT $=$ phenotypes, where $\mathrm{R}=$ resistant, $<5$ white females/plant; $\mathrm{MR}=$ moderately resistant, 5 to 10 white females/plant; $\mathrm{MS}=$ moderately susceptible, 11 to 14 white females/plant; $\mathrm{S}=$ susceptible, 15 to 25 white females/plant; and $\mathrm{HS}=$ highly susceptible, $>25$ white females/plant.

${ }^{\mathrm{z}}$ Nematode species, province, and population. 
Greenhouse assessment of reactions to $\mathrm{CCN}$. Cysts were collected separately from the infested soil in fields where tests were conducted and other wheat fields (Table 1), incubated at $4^{\circ} \mathrm{C}$ for about 10 weeks, and hatched at $15 \pm 2{ }^{\circ} \mathrm{C}$ in the dark for 3 to 4 weeks to produce second-stage juveniles (J2). To prepare inocula for greenhouse tests, the $\mathrm{J} 2$ were suspended in sterile distilled water at a concentration of $200 \mathrm{~J} 2 \mathrm{ml}^{-1}$ using a hemacytometer under a light microscope (Olympus C42). Plants were grown in polyvinylchloride tubes (13 $\mathrm{cm}$ tall by $3 \mathrm{~cm}$ in diameter), which were filled with a mixture of loam and sand (7:3). Seed were germinated on wet filter paper for 2 days at $25^{\circ} \mathrm{C}$. A single germinated seed was sown in each tube, inoculated with $800 \mathrm{~J} 2$ after seeding, and grown in a growth chamber at $15 \pm 2^{\circ} \mathrm{C}$ with a photoperiod of $12 \mathrm{~h}$ of light and $12 \mathrm{~h}$ of darkness. The number of white females on roots of each plant was counted 75 days after inoculation. Ten replicate plants were tested for each cultivar and population of $\mathrm{CCN}$; two experiments were conducted and each was arranged in a randomized complete block design.

Penetration of wheat roots by juvenile nematodes. Two-dayold plants of Madsen, Taikong 6, and Wenmai 19 were inoculated with $800 \mathrm{~J} 2 /$ plant. The conditions for plant growth and inoculation described above were applied in the study of root penetration by juvenile nematodes. A sodium hypochlorite-acid fushsin method was used to stain the roots 25 days after inoculation (Yuan et al. 2010). The number of $\mathrm{J} 2$ entirely inside the roots of a plant was determined under an optical microscope (Olympus C42). Three replicates consisting of two plants for each cultivar were inoculated. This experiment was conducted twice using a randomized complete block design.

Assessment of reactions to powdery mildew at the seedling stage. The reactions of the wheat entries to $20 \mathrm{~B}$. graminis $\mathrm{f}$. sp. tritici isolates were determined using the detached-leaf-segment method (Limpert et al. 1988). Wheat plants were grown in a greenhouse at $20 \pm 3^{\circ} \mathrm{C}$, with a photoperiod of $12 \mathrm{~h}$ of light and $12 \mathrm{~h}$ of darkness. Primary leaf segments about $3 \mathrm{~cm}$ long were removed from seedlings at the two-leaf stage and placed on the surface of $0.6 \%$ water agar plates (wt/vol) supplemented with benzimidazole at $50 \mathrm{mg}$ liter $^{-1}$ and inoculated with conidia of each $B$. graminis f. sp. tritici isolate by separately shaking plants of 'Zhongzuo 9504' that were fully sporulating over the plates. Inoculated leaf segments were incubated in covered petri dishes placed in a growth cabinet at $18 \pm$ $3^{\circ} \mathrm{C}$ with a photoperiod of $12 \mathrm{~h}$ of light and $12 \mathrm{~h}$ of darkness and $80 \%$ relative humidity. Ten days after inoculation, the infection type (IT) for each leaf segment was visually rated on a 0-to-4 scale, where $0=$ no visible symptom, $0 ;=$ necrotic flecks, $1=$ necrosis with low sporulation, $2=$ necrosis with moderate sporulation, $3=$ no necrosis with moderate to high sporulation, and $4=$ no necrosis with full sporulation. Three leaf segments from each genotype were tested using a randomized complete block design and this experiment was conducted twice. Based on the IT of the leaf segments, the cultivars were regarded as either resistant (IT 0 to 2) or susceptible (IT 3 to 4 ) to a $B$. graminis f. sp. tritici isolate.

Molecular detection of $2 \mathrm{NS}$ chromosome fragment of A. ventricosa. Genomic DNA was extracted from young leaves following the cetyltrimethylammonium bromide protocol (SaghaiMaroof et al. 1984). A pair of primers-VRGA-F11 (5'-AATC CAAAGGTCAGCAATCC-3') and VRGA-R5 (5'-GGAATC CAGGTCCTTGAGGAAC-3')—were designed to amplify a 285-bp fragment specific for gene VrgalD that is linked to the 2NS fragment of $A$. ventricosa (Fang et al. 2011). The reaction mixture (25 $\mu \mathrm{l})$ contained $50 \mathrm{ng}$ of template DNA, $0.2 \mu \mathrm{M}$ forward and reverse primers, $1 \mathrm{U}$ of Taq polymerase, dNTP at $150 \mu \mathrm{mol} \operatorname{liter}^{-1}$, and $2 \mu \mathrm{l}$ of $10 \times$ buffer with $20 \mathrm{mM} \mathrm{Mg}^{2+}$. The amplification was programmed at $94^{\circ} \mathrm{C}$ for $5 \mathrm{~min}$; followed by 40 cycles of $94^{\circ} \mathrm{C}$ for $30 \mathrm{~s}, 55^{\circ} \mathrm{C}$ for $30 \mathrm{~min}$, and $72^{\circ} \mathrm{C}$ for $30 \mathrm{~s}$; and a final extension at $72^{\circ} \mathrm{C}$ for $10 \mathrm{~min}$. The polymerase chain reaction (PCR) products were separated on an $8 \%$ nondenaturing polyacrylamide gel in $1 \times$ Tris-borate EDTA buffer (90 mM Tris-borate, $\mathrm{pH} 8.3$, and 2 mM EDTA) and visualized by silver staining.

Statistical analysis. Statistical analysis of all data was performed with SAS (version 8.0; SAS Institute). Analysis of variance (ANOVA) was performed on the mean of white females per plant that were logarithmically transformed by $\ln (x+1)$. Means and standard errors for the number of white females were determined to represent each cultivar.

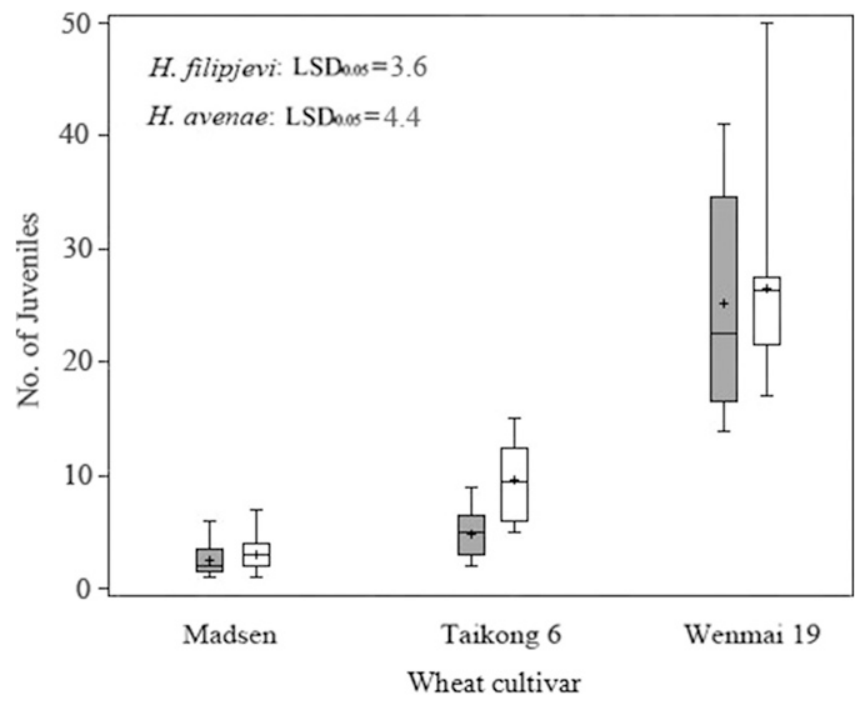

Fig. 3. Number of juvenile nematodes 25 days after inoculation with Heterodera filipjevi and H. avenae for Madsen, Taikong 6, and Wenmai 19. LSD = least significant difference.

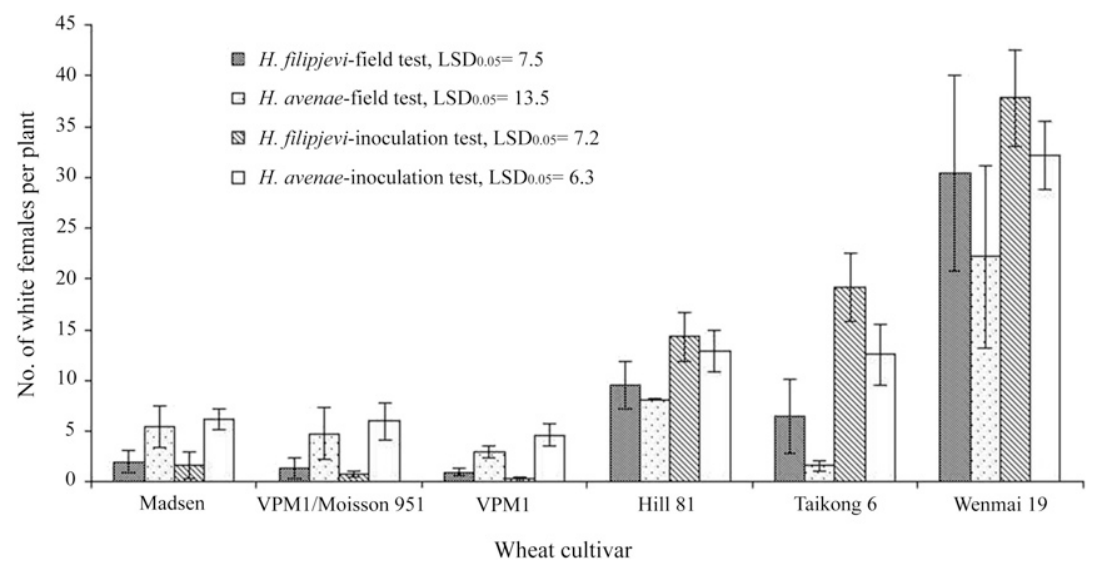

Fig. 2. Reactions of wheat cultivars to Heterodera filipjevi and H. avenae under field conditions at Xuchang and Xingyang, Henan Province in 2012 and 2013 , and artificial inoculation in the greenhouse. LSD = least significant difference. 


\section{Results}

Reaction of Madsen and its parents to $H$. filipjevi and $H$. avenae in field and greenhouse studies. The roots of Madsen and other resistant wheat genotypes developed normally, whereas the susceptible wheat Wenmai 19 had bushy roots characteristic of CCN infection (Fig. 1).

Based on ANOVA of the 2012 and 2013 cropping seasons, there was no significant year-genotype interaction $(P>0.05)$; therefore, data from both years were pooled for statistical analysis. Both Heterodera spp. produced a small number of white females on the roots of Madsen and its parents VPM1/Moisson 951 and VPM1 (Fig. 2). These genotypes exhibited a resistant phenotype in the field tests under natural infestation with $H$. filipjevi and $H$. avenae. Hill 81 , the other parent of Madsen, had 9.5 \pm 2.3 and $8.1 \pm 0.1$ white females per plant in the fields where $H$. filipjevi and $H$. avenae occurred, respectively, showing a moderately resistant phenotype. Wenmai 19 had a significantly greater number of white females per plant than any other wheat genotypes tested in both locations $(P<$ 0.05 ), and exhibited a highly susceptible phenotype to both nematode species.

When inoculated against $H$. filipjevi in greenhouse, the number of white females per plant for Madsen $(2.0 \pm 1.1)$ was similar to the parental lines VPM1/Moisson $951(1.4 \pm 1.0)$ and VPM1 $(1.0 \pm 0.4)$ (Fig. 2). Hill 81 had $14.3 \pm 2.4$ white females per plant, which was significantly greater than Madsen but less than the susceptible
Wenmai 19 . When tested against $H$. avenae, the number of white females per plant for Madsen was not significantly different from VPM1/Moisson 951 and VPM1. The number of white female $H$. avenae on roots of Hill $81(12.9 \pm 1.9)$ was greater than Madsen. The number of white females per plant for Wenmai 19 was greater than that of all other wheat genotypes examined $(P<0.05)$.

Penetration of the roots of Madsen, Taikong 6, and Wenmai 19 by juvenile nematodes. Juveniles of both $H$. filipjevi and $H$. avenae penetrated roots of Madsen, Taikong 6, and Wenmai 19 regardless of their resistance to $\mathrm{CCN}$ when roots were examined 25 days after inoculation (Fig. 3). However, the number of $H$. filipjevi and $H$. avenae juveniles in the resistant Madsen (2.5 \pm 0.4 and $3.1 \pm 0.5$, respectively) and moderately resistant Taikong $6(4.8 \pm 0.6$ and $9.6 \pm 1.1$, respectively) were significantly less than those in the susceptible Wenmai $19(25.2 \pm 2.8$ and $26.5 \pm 2.5$, respectively) $(P<0.05)$. The number of $H$. avenae juveniles in roots of Madsen was also significantly less than that of Taikong $6(P<0.05)$. Overall, the number of the $H$. avenae juveniles in the roots of all three cultivars $(13.1 \pm$ 1.9) was slightly greater than that of $H$. filipjevi $(10.8 \pm 2.0)$ but the difference was not significant $(t=0.815, P=0.4178)$.

Reactions of Madsen and VPM1 to different populations of H. filipjevi and $\boldsymbol{H}$. avenae. Artificial inoculation studies were performed with five $H$. filipjevi and seven $H$. avenae populations from different wheat fields in Henan, Shandong, and Anhui Provinces (Table 1). No white females were present on the roots of Madsen

Table 2. Reaction of wheat cultivars to 20 isolates of Blumeria graminis f. sp. tritici collected in China ${ }^{\mathrm{z}}$

\begin{tabular}{|c|c|c|c|c|c|c|c|}
\hline Isolate & $\begin{array}{l}\text { Avirulence/virulence on powdery } \\
\text { mildew resistance genes }\end{array}$ & Madsen & VPM/Moisson951 & VPM1 & Hill 81 & Taikong 6 & Wenmai 19 \\
\hline 1 & $\begin{array}{c}1 \mathrm{a}, 1 \mathrm{c}, 2,3 \mathrm{~b}, 3 \mathrm{c}, 4 \mathrm{a}, 4 \mathrm{~b}, 5 \mathrm{e}, 6,13,17, \\
21,24,33,48 / 3,3 \mathrm{~g}, 5 \mathrm{a}, 7,8,19\end{array}$ & 3 & 0 & 0 & 3 & 3 & 3 \\
\hline 2 & $\begin{array}{c}\text { 1a, } 1 \mathrm{c}, 2,4 \mathrm{a}, 4 \mathrm{~b}, 5 \mathrm{e}, 6,13,21,24 \\
, 33,48 / 3,3 \mathrm{~b}, 3 \mathrm{c}, 3 \mathrm{~g}, 5 \mathrm{a}, 7,8,19\end{array}$ & 3 & 0 & 0 & 3 & 4 & 2 \\
\hline 3 & $\begin{array}{l}\text { 1a, } 1 \mathrm{c}, 2,3 \mathrm{~b}, 3 \mathrm{c}, 5 \mathrm{e}, 13,17,21 \\
24,33,48 / 3 \mathrm{a}, 3 \mathrm{~g}, 4 \mathrm{a}, 4 \mathrm{~b}, 5 \mathrm{a}, 6,7,8\end{array}$ & 3 & 3 & 3 & 3 & 3 & 3 \\
\hline 4 & $\begin{array}{l}\text { 1a, 1c, } 2,3 \mathrm{~b}, 4 \mathrm{a}, 4 \mathrm{~b}, 5 \mathrm{e}, 6,13,17 \\
21,24,33,48 / 3 \mathrm{a}, 3 \mathrm{c}, 3 \mathrm{~g}, 5 \mathrm{a}, 7,8,19\end{array}$ & 3 & 0 & 1 & 3 & 3 & 3 \\
\hline 5 & $\begin{array}{l}\text { 1a,1c,2,3g,4a, 4b,5e,13,21, } \\
24,33,48 / 3,3 \mathrm{~b}, 3 \mathrm{c}, 5 \mathrm{a}, 6,7,8,19\end{array}$ & 4 & 0 & 0 & 3 & 4 & 3 \\
\hline 6 & $\begin{array}{l}\text { 1a, 1c }, 2,3,4 \mathrm{a}, 4 \mathrm{~b}, 5 \mathrm{e}, 13,21, \\
24,33,48 / 3 \mathrm{~b}, 3 \mathrm{c}, 3 \mathrm{~g}, 5 \mathrm{a}, 6,7,8,19\end{array}$ & 4 & 0 & 1 & 4 & 4 & 3 \\
\hline 7 & $\begin{array}{l}\text { 1a, } 1 \mathrm{c}, 2,3 \mathrm{~b}, 5 \mathrm{e}, 13,17,21,24, \\
48 / 3,3 \mathrm{c}, 3 \mathrm{~g}, 4 \mathrm{a}, 4 \mathrm{~b}, 5 \mathrm{a}, 6,8,19,33\end{array}$ & 3 & 3 & 3 & 0 & 4 & 4 \\
\hline 8 & $\begin{array}{c}\text { 1a, } 1 \mathrm{c}, 2,5 \mathrm{e}, 8,13,21,24,48 / 3 \\
3 \mathrm{~b}, 3 \mathrm{c}, 3 \mathrm{~g}, 4 \mathrm{a}, 4 \mathrm{~b}, 5 \mathrm{a}, 6,7,19,33\end{array}$ & 3 & 3 & 3 & 3 & 3 & 3 \\
\hline 9 & $\begin{array}{c}3 \mathrm{~b}, 3 \mathrm{c}, 5 \mathrm{a}, 5 \mathrm{e}, 13,17,21,24,48 / 1 \mathrm{a} \\
1 \mathrm{c}, 2,3,3 \mathrm{~g}, 4 \mathrm{a}, 4 \mathrm{~b}, 6,7,8,19,33\end{array}$ & 3 & - & 3 & - & 3 & 3 \\
\hline 10 & $\begin{array}{l}\text { 1a,1c, } 2,5 \mathrm{e}, 13,21,24,33,48 / 3 \\
3 \mathrm{~b}, 3 \mathrm{c}, 3 \mathrm{~g}, 4 \mathrm{a}, 4 \mathrm{~b}, 5 \mathrm{a}, 6,7,8,17,19\end{array}$ & 3 & 3 & 3 & 0 & 3 & 3 \\
\hline 11 & $\begin{array}{l}1 \mathrm{c}, 2,5 \mathrm{e}, 6,8,13,17,21,24,33, \\
48 / 1 \mathrm{a}, 3,3 \mathrm{~b}, 3 \mathrm{c}, 3 \mathrm{~g}, 4 \mathrm{a}, 4 \mathrm{~b}, 5 \mathrm{a}, 7,19\end{array}$ & 0 & 0 & 0 & 3 & 3 & 3 \\
\hline 12 & $\begin{array}{c}1 \mathrm{c}, 2,3,3 \mathrm{~b}, 3 \mathrm{c}, 3 \mathrm{~g}, 4 \mathrm{a}, 4 \mathrm{~b}, 5 \mathrm{a}, 5 \mathrm{e} \\
6,13,17,21,24,33,48 / 1 \mathrm{a}, 8,19\end{array}$ & 1 & 0 & 1 & 3 & 3 & 3 \\
\hline 13 & $\begin{array}{l}1 \mathrm{c}, 3 \mathrm{~b}, 3 \mathrm{~g}, 4 \mathrm{a}, 4 \mathrm{~b}, 5 \mathrm{e}, 6,13,17 \\
21,24,33,48 / 1 \mathrm{a}, 2,3,3 \mathrm{c}, 5 \mathrm{a}, 7,8,19\end{array}$ & 3 & 0 & 0 & 0 & 3 & 3 \\
\hline 14 & $\begin{array}{l}\text { 1a,1c,2,3,4a,4b,6,17,21,24, } \\
33,48 / 3 \mathrm{~b}, 3 \mathrm{c}, 3 \mathrm{~g}, 5 \mathrm{a}, 5 \mathrm{e}, 7,8,13,19\end{array}$ & 0 & 2 & 0 & 0 & 3 & 3 \\
\hline 15 & $\begin{array}{l}\text { 1a, 1c, } 2,3 \mathrm{~b}, 4 \mathrm{a}, 4 \mathrm{~b}, 5 \mathrm{e}, 13,21 \\
24,33,48 / 3,3 \mathrm{c}, 3 \mathrm{~g}, 5 \mathrm{a}, 6,7,8,17,19\end{array}$ & 3 & 0 & 0 & 0 & 3 & 3 \\
\hline 16 & $\begin{array}{c}\text { 1a, 1c, } 2,3 \mathrm{~b}, 5 \mathrm{e}, 13,21,24,48 / 3 \\
3 \mathrm{c}, 3 \mathrm{~g}, 4 \mathrm{a}, 4 \mathrm{~b}, 5 \mathrm{a}, 6,7,8,17,19,33\end{array}$ & 3 & 3 & 3 & 3 & 4 & 3 \\
\hline 17 & $\begin{array}{c}1 \mathrm{c}, 2,4 \mathrm{a}, 4 \mathrm{~b}, 5 \mathrm{e}, 21,24,33,48 / 1 \mathrm{a} \\
3 \mathrm{a}, 3 \mathrm{~b}, 3 \mathrm{c}, 3 \mathrm{~g}, 5 \mathrm{a}, 6,7,8,13,19\end{array}$ & 4 & 1 & 1 & 4 & 4 & 3 \\
\hline 18 & $\begin{array}{l}\text { 1c,2,4a,4b,5e,13,21,24,33, } \\
\text { 48/1a,3a,3b,3c,3g,5a,6,7,8,19 }\end{array}$ & 4 & 0 & 0 & 4 & 4 & 4 \\
\hline 19 & $\begin{array}{c}\text { 1a, 1c, } 2,3 \mathrm{~b}, 4 \mathrm{a}, 4 \mathrm{~b}, 4 \mathrm{c}, 5 \mathrm{e}, 6,13,17 \\
21,24,33,48 / 3 \mathrm{a}, 3 \mathrm{c}, 3 \mathrm{~g}, 5 \mathrm{a}, 7,8,19\end{array}$ & 4 & 0 & 0 & 3 & 4 & 4 \\
\hline 20 & $\begin{array}{c}1 \mathrm{c}, 2,5 \mathrm{e}, 13,17,21,24,48 / 1 \mathrm{a}, 3 \mathrm{a}, 3 \mathrm{~b} \\
3 \mathrm{c}, 3 \mathrm{~g}, 4 \mathrm{a}, 4 \mathrm{~b}, 4 \mathrm{c}, 5 \mathrm{a}, 6,7,8,19,33\end{array}$ & 4 & 3 & 4 & 4 & 4 & 4 \\
\hline
\end{tabular}

\footnotetext{
$\mathrm{z}$ The infection type (IT) for each leaf segment was visually rated on a 0 -to- 4 scale, where $0=$ no visible symptom, $0 ;=$ necrotic flecks, $1=$ necrosis with low
} sporulation, 2 = necrosis with moderate sporulation, $3=$ no necrosis with moderate to high sporulation, and $4=$ no necrosis with full sporulation. 
when inoculated with $H$. filipjevi populations from Xuchang, Linying, and Huaiyang, Henan Province; however, a few white females (2.2 \pm 1.2) were observed when inoculated with the $H$. filipjevi population from Luolong, Henan Province. Although Madsen had a moderately susceptible phenotype to the Boai population of $H$. filipjevi, the number of white females per plant $(11.0 \pm 4.3)$ was less than on Taikong 6 $(40.5 \pm 7.0)$ and Wenmai $19(44.5 \pm 24.6)$. VPM1 was resistant to the three $H$. filipjevi populations from Xuchang, Linying, and Luolong, Henan Province. Taikong 6 was resistant to the Xuchang population but susceptible to all other $H$. filipjevi populations, with the number of white females ranging from $22.6 \pm 3.2$ (Linying population) to $96.4 \pm$ 18.7 (Luolong population). Wenmai 19 was susceptible to all populations, with the number of white females ranging from $21.0 \pm 5.6$ (Xuchang population) to $119.3 \pm 21.6$ (Luolong population).

Madsen had a highly resistant reaction to the $H$. avenae populations from Yanjin, Qixian, and Qingfeng, Henan Province; Heze, Shandong Province; and Yingshang, Anhui Province, and was moderately resistant to the population from Xingyang, Henan Province; however, it was moderately susceptible to the $H$. avenae populations from Shangqiu, Henan Province. Similarly, VPM1 was highly resistant to Yanjin, Heze, and Yingshang populations and moderately resistant to Xingyang population but moderately susceptible to Shangqiu population. Taikong 6 was moderately to highly susceptible to all $H$. avenae populations, except Xingyang population, to which it was moderately resistant. Wenmai 19 was highly susceptible to all $H$. filipjevi and $H$. avenae populations (Table 1).

Reactions of Madsen and its parents to a set of $B$. graminis $\mathbf{f}$. sp. tritici isolates. VPM1 was resistant (IT 0 or 1) to 13 of $20 \mathrm{~B}$. graminis f. sp. tritici isolates but was susceptible (IT 3 or 4 ) to the other 7 isolates (Table 2). The reaction of line VPM1/Moisson 951 resembled that of VPM1. Madsen had an IT of 0 or 1 when tested against B. graminis f. sp. tritici isolates 10,11, and 13, whereas it had IT 3 or 4 reactions to the remaining 17 isolates. Hill 81 was resistant to 5 isolates but susceptible to the other 15 isolates. Wenmai 19 and Taikong 6 were not resistant to any of the $20 \mathrm{~B}$. graminis f. sp. tritici isolates.

Detection of 2NS chromosomal segment. The primer pair VRGA-F11 and VRGA-R5 amplified the 285-bp band diagnostic for the 2NS translocation in A. ventricosa line 10, VPM1, Madsen, and VPM1/Moisson 951 (Fig. 4). In contrast, Hill 81, Taikong 6, and Wenmai 19 produced a different band that was larger than $285 \mathrm{bp}$, indicating the absence of the $2 \mathrm{NS}$ fragment. This result indicates that the 2NS fragment from A. ventricosa is present in Madsen.

\section{Discussion}

Based on the results of repeated field and greenhouse tests, the soft white winter wheat Madsen grown in the PNW region of the United States was identified as a valuable source of resistance to both species of CCN, H. filipjevi and $H$. avenae, which are indigenous to China. Fewer juvenile nematodes penetrated the roots of Madsen than susceptible wheat genotypes and, thus, the final number of white female nematodes was less near the end of the plant life cycle. Madsen was resistant to $H$. filipjevi and $H$. avenae populations from different wheat-producing regions in northern China, especially those from Henan Province, where $\mathrm{CCN}$ has resulted in severe damage to wheat production. $H$. avenae and $H$. filipjevi occurred simultaneously in some places (for example, Henan Province), and different pathotypes of both Heterodera spp. have been documented in different wheatproducing regions in China (Fu et al. 2011). The existence of multiple species and pathotypes of CCN complicates breeding for host resistance because resistance to one species of Heterodera does not necessarily mean resistance to the other species (Mokabli et al. 2002). Therefore, the identification of Madsen as an effective source of resistance to different populations of both Heterodera spp. offers an opportunity for reducing the economic loss arising from $\mathrm{CCN}$ infestation with host resistance, given the shortage of resistance resources (Li et al. 2012) that constrains current breeding efforts for improving $\mathrm{CCN}$ resistance of wheat.

Among the wheat cultivars involved in the pedigree of Madsen, VPM1 and its derived line VPM1/Moisson 951 were both resistant to $\mathrm{CCN}$, whereas Hill 81 was susceptible. Previously, Moisson was shown to be susceptible to $H$. avenae and VPM1 was shown to carry $\mathrm{Cre} 5$ for resistance against pathotype Ha12 from Saint Christophe Le Jajoilet, France (Jahier et al. 2001). VPM1 and its derived cultivars were also resistant to several pathotypes of $H$. avenae from Australia (Ha12 and Ha13) (Ogbonnaya et al. 2001), Spain (Ha71) (Montes et al. 2003), and the United States (Smiley et al. 2013). Based on these findings, CCN resistance in Madsen was most likely inherited from VPM1 via VPM1/Moisson 951; however, the presence of $\mathrm{Cre5}$ was not always associated with resistance to $\mathrm{CCN}$ (Dababat et al. 2014). Molecular mapping is underway to determine the gene or QTL for resistance to CCN in Madsen.

Madsen was a widely grown cultivar in the PNW following its release in Washington in 1987 (Allan et al. 1989). It has been the primary source of resistance to eyespot of wheat (caused by Oculimacula spp.) because of gene Pchl on the translocated chromosome between 7NS of $A$. ventricosa and 7DL of wheat (Strausbaugh and Murray 1989). In addition, Madsen is resistant to stem rust, leaf rust, and stripe rust (caused by Puccinia graminis f. sp. tritici, P. triticina, and $P$. striiformis $\mathrm{f}$. sp. tritici, respectively), which is derived from VPM1. A cluster of genes including Sr38, Lr37, and Yr17 are present on the A. ventricosa chromosome $2 \mathrm{NS}$ segment that was transferred to chromosome 2AS of wheat is responsible for the resistance to these rusts (Bariana and McIntosh 1994). Using a pair of PCR primers specific for Vrgal on chromosome segment 2NS (VRGA-F11 and VRGA-R5; Fang et al. 2011), the presence of a 2NS fragment was detected in Madsen, which is consistent with a previous study using a different pair of primers specific for 2NS (Helguera et al. 2003). VPM1 has been used in developing many wheat cultivars in Europe and North America as well as China (Dedryver et al. 2009; Hanzalová et al. 2009; Li et al. 2009) because the 2NS fragment does not have any linkage drag or deleterious effects on wheat yield and quality (Cane et al. 2008). Madsen has also been used as a parent in developing wheat cultivars (Jones et al. 2006). It would be valuable to examine VPM1- or Madsen-derived cultivars to identify other CCN-resistant cultivars with different genetic backgrounds.

Difference in reproductive capacity of certain $H$. avenae and $H$. filipjevi populations was observed in resistant and susceptible wheat genotypes (Rivoal et al. 2001). Plants may possess an intrinsic ability to prevent penetration of cyst nematodes into the roots by exudation of repellents (Huang 1998). Differences in formation and development of syncytia was confirmed in the resistant and susceptible wheat genotypes that carry genes $\mathrm{Crel}$ and $\mathrm{Cre} 3$ for resistance to CCN when tested using H. avenae (Seah et al. 2000). The

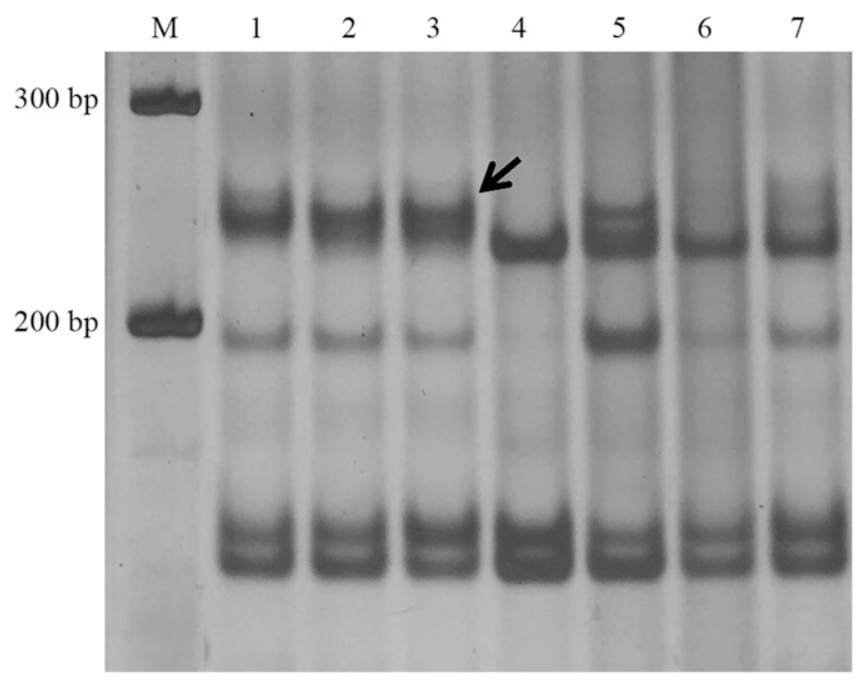

Fig. 4. Detection of chromosome 2NS fragments from Aegilops ventricosa in Madsen using the molecular markers VRGA-F11/VRGA-R5. M: 100-bp DNA ladder; lane 1: $A$ ventricosa line 10; lane 2: VPM1; lane 3: Madsen; lane 4: Hill 81 ; lane 5 : VPM1/Moission 951; lane 6: Taikong 6; lane 7: Wenmai 19. The diagnostic 285-bp band is shown by an arrow. 
development of syncytia was accelerated in the resistant plants. However, the syncytia formed in the resistant plants degenerated in later stages of the host-nematode interaction that prevented further development of the nematodes inside the roots. In this study, fewer J2 were observed in the resistant Madsen than in the susceptible Wenmai 19. This suggests that another mechanism of resistance in Madsen may exist or in addition to syncytia breakdown.

Powdery mildew is another important disease in the wheatproducing regions where $\mathrm{CCN}$ occurs in China. Even though VPM1 was resistant to $13 \mathrm{~B}$. graminis f. sp. tritici isolates due to the presence of Pm $4 b$ from $T$. persicum on chromosome 2AL (Bariana and McIntosh 1994), Madsen was susceptible to most of the 20 B. graminis f. sp. tritici isolates examined. Incorporation of powdery mildew resistance is needed when Madsen is used as a source of $\mathrm{CCN}$ resistance. A series of lines that carry Pm52 (= MlLX99) for resistance to powdery mildew were created by crossing Madsen with 'Liangxing 99' (Zhao et al. 2013), and lines with resistance to both CCN and powdery mildew have been identified that should be useful parents in developing wheat cultivars with resistance against these pathogens (H. J. Li, unpublished data).

\section{Acknowledgments}

We thank J. Jahier for providing seed of VPM1 and the Aegilops ventricosa accessions; and the National Natural Science Foundation (31171545), China Agricultural Research Service (CARS-3-2), and the CAAS Innovation Team Project for providing financial support.

\section{Literature Cited}

Abidou, H., Valette, S., Gauthier, J. P., Rivoal, R., El-Ahmed, A., and Yahyaoui, A. 2005. Molecular polymorphism and morphometrics of species of the Heterodera avenae group in Syria and Turkey. J. Nematol. 37:146-154

Allan, R. E., Peterson, C. J., Rubenthaler, G. L., Line, R. F., and Roberts, D. E. 1989. Registration of Madsen wheat (Reg. No. 746). Crop Sci. 29: 1575-1576.

Bariana, H. S., and McIntosh, R. A. 1994. Characterisation and origin of rust and powdery mildew resistance genes in VPM1 wheat. Euphytica 76:53-61.

Cane, K., Sharp, P. J., Eagles, H. A., Eastwood, R. F., Hollamby, G. J., Kuchel, H., Lu, M. Q., and Martin, P. J. 2008. The effects on grain quality traits of a grain serpin protein and the VPM1 segment in southern Australian wheat breeding. Aust. J. Agric. Res. 59:883-890.

Dababart, A. A., Orakci, G. E., Toktay, H., İmren, M., Akin, B., Braun, H. J., Dreisigacker, S., Elekçioğlu, İ. H., and Morgounov, A. 2014. Resistance of winter wheat to Heterodera filipjevi in Turkey. Turk. J. Agric. For. 38: 180-186.

Dedryver, F., Paillard, S., Mallard, S., Robert, O., Trottet, M., Nègre, S., Verplancke, G., and Jahier, J. 2009. Characterization of genetic components involved in durable resistance to stripe rust in the bread wheat 'Renan'. Phytopathology 99:968-973.

Delibes, A., Romero, D., Aguaded, S., Duce, A., Mena, M., Lopez-Braña, I., Andrés, M. F., Martin-Sanchez, J. A., and García-Olmedo, F. 1993. Resistance to the cereal cyst nematode (Heterodera avenae Woll.) transferred from the wild grass Aegilops ventricosa to hexaploid wheat by a "steppingstone" procedure. Theor. Appl. Genet. 87:402-408.

Eastwood, R. F., Lagudah, E. S., and Appels, R. 1994. A directed search for DNA sequences tightly linked to cereal cyst nematode resistance genes in Triticum tauschii. Genome 37:311-319.

Elekçioğlu, İ. H., Nicol, J. M., Bolat, N., Şahin, E., Yorgancilar, A., Braun, H. J., Yorgancilar, O., Yildirim, A. F., Kilinc, A. T., Toktay, H., and Calişian, M. 2009. Longterm studies on the cereal cyst nematode Heterodera filipjevi in Turkey: International collaboration with regional implications. Pages 11-16 in: Cereal Cyst Nematodes: Status, Research and Outlook. I. T. Riley, J. M. Nicol, and A. A. Dababat, eds. CIMMYT, Ankara, Turkey.

Fang, T. L., Campbell, K. G., Liu, Z. Y., Chen, X. M., Wan, A. M., Li, S., Liu, Z. J., Cao, S. H., Chen, Y. H., Bowden, R. L., Carver, B. F., and Yan, L. L. 2011. Stripe rust resistance in the wheat cultivar Jagger is due to $\mathrm{Yrll}$ and a novel resistance gene. Crop Sci. 51:2455-2465.

Fu, B., Yuan, H. X., Zhang, Y., Hou, X. S., Nian, G. L., Zhang, P., Xing, X. P., Sun, B. J., Riley, I. T., and Li, H. L. 2011. Molecular characterization of cereal cyst nematodes in winter wheat on the Huang-Huai floodplain of China using RFLP and rDNA ITS sequence analyses. Australas. Plant Pathol. 40:277-285.

Gao, X., Cui, L., Li, H. L., Wang, X. M., Tang, W. H., Conner, R. L., Lin, X. H., and Li, H. J. 2012. Resistance of Triticum durum cultivars Waskana and Waskooma to cereal cyst nematode caused by Heterodera filipjevi and H. avenae. Acta Agron. Sin. 39:571-577.

Hanzalová, A., Sumiková, T., and Bartoš, P. 2009. Determination of leaf rust resistance genes $L r 10, L r 26$ and $L r 37$ by molecular markers in wheat cultivars registered in the Czech Republic. Czeck J. Genet. Plant Breed. 45:79-84.
Helguera, M., Khan, I. A., Kolmer, J., Lijavetzky, D., Zhong-qi, L., and Dubcovsky, J. 2003. PCR assays for the Lr37-Yr17-Sr38 cluster of rust resistance genes and their use to develop isogenic hard red spring wheat lines. Crop Sci. 43:1839-1847.

Holgado, R., Andersson, S., Rowe, J. A., and Magnusson, C. 2004. First record of Heterodera filipjevi in Norway. Nematol. Mediterr. 32:205-211.

Huang, J.-S. 1998. Mechanisms of resistance. Pages 353-368 in: The Cyst Nematodes. S. B. Sharma, ed. Chapman \& Hall, London.

İmren, M., Toktay, H., Bozbuğa, R., Erginbaş Orakci, G., Dababat, A., and Elekçioğlu, İ. H. 2013. Identification of genetic resistance to cereal cyst nematodes; Heterodera avenae (Wollenweber, 1924), Heterodera filipjevi (Madzhidov, 1981) Stelter and Heterodera latipons (Franklin, 1969) in some international bread wheat germplasms. Turk. J. Entomol. 37:277-282.

Jahier, J., Abelard, P., Tonguy, A. M., Dedryver, F., Rivoal, R., Khatkar, R., and Bariana, H. S. 2001. The Aegilops ventricosa segment on chromosome $2 \mathrm{AS}$ of the wheat cultivar 'VPM1' carries the cereal cyst nematode gene Cre5. Plant Breed. 120:125-128.

Jahier, J., Tanguy, A. M., Abelard, P., and Rivoal, R. 1996. Utilization of deletions to localize a gene for resistance cereal cyst nematode (Heterodera avenae), on an Aegilops ventricosa chromosome. Plant Breed. 115:282-284.

Jones, S. S., Lyon, S. R., Balow, K. A., Murray, T. D., Chen, X. M., Carter, B. P., Morris, C. R., Garland-Campbell, K., Burns, J. W., Schillinger, W. F., Reisenauer, P. E., and Goates, B. J. 2006. Registration of 'Masami' wheat. (Abstr.) Crop Sci. 46:476.

Li, F. Q., Han, D. J., Wei, R. G., Zeng, Q. D., and Kang, Z. S. 2009. Identification of Lr37-Yr17-Sr38 in wheat cultivars of Huanghuai wheat region using molecular markers. J. Northwest A\&F Univ. (Nat. Sci. Ed.) 37:151-158.

Li, H. J., Cui, L., Li, H. L., Wang, X. M., Murray, T. D., Conner, R. L., Wang, L. J., Gao, X., Sun, Y., Sun, S. C., and Tang, W. H. 2012. Effective resources of wheat and wheat-Thinopyrum derivatives for resistance to Heterodera filipjevi in China. Crop Sci. 52:1209-1217.

Li, H. L., Yuan, H. X., Sun, J. W., Fu, B., Nian, G. L., Hou, X. S., Xing, X. P., and Sun, B. J. 2010. First record of the cereal cyst nematode Heterodera filipjevi in China. Plant Dis. 94:1505.

Limpert, E., Andrivon, D., and Felsenstein, F. G. 1988. Influence of different benzimidazole concentrations in agar medium on senescence of wheat leaf segments and on growth and sporulation of the wheat powdery mildew pathogen. J. Plant Dis. Prot. 95:301-306.

Mokabli, A., Valette, S., Gauthier, J.-P., and Rivoal, R. 2002. Variation in virulence of cereal cyst nematode populations from North Africa and Asia. Nematology 4:521-525.

Montes, M. J., López-Braña, I., Romero, M. D., Sin, E., Andrés, M. F., MartínSánchez, J. A., and Delibes, A. 2003. Biochemical and genetic studies of two Heterodera avenae resistance genes transferred from Aegilops ventricosa to wheat. Theor. Appl. Genet. 107:611-618.

Nicol, J. M., Bolat, N., Yildirim, A. F., Yorgancilar, A., Kilinç, A. T., Elekçioğlu, İ. H., Şahin, E., Erginbaş-Orakci, G., and Braun, H. J. 2009. Identification of genetic resistance to cereal cyst nematode (Heterodera filipjevi) for international bread wheat improvement. Pages 160-165 in: Cereal Cyst Nematodes: Status, Research and Outlook. I. T. Riley, J. M. Nicol, and A. A. Dababat, eds. CIMMYT, Ankara, Turkey.

Ogbonnaya, F. C., Seah, S., Delibes, A., Jahier, J., López-Braña, I., Eastwood, R. F., and Lagudah, E. S. 2001. Molecular-genetic characterisation of a new nematode resistance gene in wheat. Theor. Appl. Genet. 102:623-629.

Paull, J. G., Chalmers, K. J., Karakousis, A., Kretschmer, J. M., Manning, S., and Langridge, P. 1998. Genetic diversity in Australian wheat varieties and breeding material based on RFLP data. Theor. Appl. Genet. 96:435-446.

Peng, D. L., Nicol, J. M., Li, H. M., Hou, S. Y., Li, H. X., Chen, S. L., Ma, P., Li, H. L., and Riley, I. T. 2009. Current knowledge of cereal cyst nematode (Heterodera avenae) on wheat in China. Pages 29-34 in: Cereal Cyst Nematodes: Status, Research and Outlook. I. T. Riley, J. M. Nicol, and A. A.Dababat, eds. CIMMYT, Ankara, Turkey.

Peng, D. L., Ye, X., Peng, H., and Gu, X. C. 2010. First report of the cyst nematode (Heterodera filipjevi) on wheat in Henan Province, China. Plant Dis. 94:1262.

Rivoal, R., Bekal, S., Valette, S., Gauthier, J. P., Fradj, M. B. H., Mokabli, A., Jahier, J., Nicol, J., and Yahyaoui, A. 2001. Variation in reproductive capacity and virulence on different genotypes and resistance genes of Triticeae, in the cereal cyst nematode species complex. Nematology 3:581-592.

Romero, M. D., Montes, M. J., Sin, E., López-Braña, I., Duce, A., Martín-Sánchez, J. A., Andrés, M. F., and Delibes, A. 1998. A cereal cyst nematode (Heterodera avenae Woll.) resistance gene transferred from Aegilops triuncialis to hexaploid wheat. Theor. Appl. Genet. 96:1135-1140.

Saghai-Maroof, M. A., Soliman, K. M., Jorgensen, R. A., and Allard, R. W. 1984 Ribosomal DNA spacer-length polymorphisms in barley: Mendelian inheritance, chromosomal locations and population dynamics. Proc. Natl. Acad. Sci. USA 81:8014-8018.

Seah, S., Miller, C., Sivasithamparam, K., and Lagudah, E. S. 2000. Roo responses to cereal cyst nematode (Heterodera avenae) in hosts with different resistance genes. New Phytol. 146:527-533.

Slootmaker, L. A. J., Lange, W., Jochemsem, G., and Schepers, J. 1974 Monosomic analysis in bread wheat of resistance to cereal root eelworm. Euphytica 23:497-503. 
Smiley, R. W., Marshall, J. M., Gourlie, J. A., Paulitz, T. C., Kandel, S. L., Pumphrey, M. O., Garland-Campbell, K., Yan, G. P., Anderson, M. D., Flowers, M. D., and Jackson, C. A. 2013. Spring wheat tolerance and resistance to Heterodera avenae in the Pacific Northwest. Plant Dis. 97: 590-600.

Smiley, R. W., and Nicol, J. M. 2009. Nematodes which challenge global wheat production. Pages 171-187 in: Wheat: Science and Trade. B. F. Carver, ed. Blackwell Publishing, Ames, IA.

Smiley, R. W., and Yan, G. P. 2015. Discovery of Heterodera filipjevi in Washington and comparative virulence with $H$. avenae on wheat. Plant Dis. 99:376-386.

Strausbaugh, C. A., and Murray, T. D. 1989. Inheritance of resistance to Pseudocercosporella herpotrichoides in three cultivars of winter wheat. Phytopathology 79:1048-1053.

Taylor, C., Shepherd, K. W., and Langridge, P. 1998. A molecular genetic map of the long arm of chromosome $6 \mathrm{R}$ of rye incorporating the cereal cyst nematode resistance gene, CreR. Theor. Appl. Genet. 97:1000-1012.
Williams, K. J., Lewis, J. G., Bogacki, P., Pallotta, M. A., Willsmore, K. L. Kuchel, H., and Wallwork, H. 2003. Mapping of a QTL contributing to cereal cyst nematode tolerance and resistance in wheat. Aust. J. Agric. Res. 54:731-737.

Yuan, H. X., Sun, J. W., Yang, W. X., Xing, X. P., Wang, Z. Y., Riley, I. T., and Li, H. L. 2010. New pathotypes of Heterodera avenae (cereal cyst nematode) from winter wheat in Zhengzhou, Henan, China. Australas. Plant Pathol. 39: 107-111.

Yuan, H. X., Zhang, F. X., Zhang, J. J., Hou, X. S., Li, H. J., and Li, H. L. 2011 Resistance of CIMMYT wheat germplasm to Heterodera filipjevi Xuchang population from Henan Province, China. Acta Agron. Sin. 37:1956-1966.

Zadoks, J. C., Chang, T. T., and Konzak, D. F. 1974. A decimal code for growth stages of cereal. Weed Res. 14:415-421.

Zhao, Z. H., Sun, H. G., Song, W., Lu, M., Huang, J., Wu, L. F., Wang, X. M., and $\mathrm{Li}$, H. J. 2013. Genetic analysis and detection of the gene MlLX99 on chromosome $2 \mathrm{BL}$ conferring resistance to powdery mildew in the wheat cultivar Liangxing 99. Theor. Appl. Genet. 126:3081-3089. 